\title{
Integrated of Technological Pedagogical and Content Knowledge (TPACK) for Pre-Service Science Teachers: Literature Review
}

\author{
Lely Nurhidayah ${ }^{1, *}$ Slamet Suyanto ${ }^{2}$ \\ ${ }^{1}$ Master of Biology Education, Faculty of Mathematics and Natural Sciences, Universitas Negeri Yogyakarta, \\ Indonesia \\ ${ }^{2}$ Department of Biology Education, Faculty of Mathematics and Natural Sciences, Universitas Negeri \\ Yogyakarta, Indonesia \\ ${ }^{*}$ Corresponding author. Email: lelynurhidayah.2019@student.uny.ac.id
}

\begin{abstract}
Teachers in the 21 st century are like today at a very rapid technological development. Teachers not only have to master understanding the content of the subject matter but also need skills in using and operating technology in learning. So that we need teachers who can integrate content and pedagogical skills with technology. The TPACK was created as the knowledge that teachers generate simultaneously and are interdependent on content, general pedagogy, technology, and learning context. This study is a literature review on the integration of the technological abilities of pedagogical content knowledge (TPACK) in pre-service science teachers by analyzing journals with the aim of 1) investigating the distribution of journals, 2) investigating the types of journal research in a percentage of $\%, 3$ ) investigating data collection methods in the journal as a percentage of $\%, 4)$ TPACK sub-dimension which is integrated with technology, and 5) the results of research related to pre-service science teacher TPACK, the analysis was carried out on 10 journals. The results of 1) the largest distribution of journals in 2016-2020 the percentage was $80 \%, 2$ ) the type of research was dominated by quantitative research by $40 \%$, 3) methods data collection for the whole journal using a questionnaire (survey), 4) sub-dimensions of the TPACK framework that integrates with technology, namely TK, TPK, and TCK, 5) technology integration is not influenced by gender differences and will increase through courses or training.
\end{abstract}

Keywords: Technology, Pedagogy, Content, Pre-service teachers and TPACK

\section{INTRODUCTION}

Teachers in the 21 st century are a time of rapid technological development like today. It is not enough for a teacher to only have the content of learning material that must be mastered, but a teacher also needs to have skills in using technology that is applied to learning. This needs to be done because the development of the 4.0 revolution which demands all timelines for technology literacy is also in the field of education. Naturally, educational activities are needed to incorporate elements of technology and their applications. In the school environment, every element that exists there must integrate itself with technology[1]. Every element that needs to do so can be said to be a stakeholder. Stakeholders, namely administrators, teachers, students, and families who have a significant interest in the incorporation of technology. Among these stakeholders, teachers have been given greater responsibility in using their teaching techniques to enhance student learning and higher-order thinking skills [2]

Because of this, where a teacher is required to have diverse competencies, namely pedagogical competence, professional competence, personality competence, and social competence. Every teacher who will teach must pass a teacher competency test to find out how his abilities and determines the quality of a teacher. In terms of understanding the subject matter, the teacher already has a good understanding. However, knowledge of how to teach requires the ability to use the right methods for teaching and how the right strategies to teach content 
to students to make it more meaningful. Therefore, it is necessary to have professional knowledge of teachers about knowledge combined with the subject matter according to their fields by utilizing various technologies in teaching known as technological pedagogical content knowledge (TPACK)[3]. The TPACK framework combines pedagogical skills, content knowledge with technology. TPACK regulates the relationship between technology, curriculum content, and specific pedagogies regarding how teachers understand technology, pedagogy, and content in helping each other to produce effective disciplines with educational technology[4].

When using any technology tool in an educational context, a teacher must be able to combine his knowledge of technology and how to use technology in a particular educational context. In this case, the integration of technology will be effective in a subject that requires a combination of three important knowledge domain elements, namely technological knowledge (TK), pedagogical knowledge (PK), and content knowledge $(\mathrm{CK})$. When these domains are combined, it will produce slices that form knowledge technology content (TCK), pedagogical knowledge technology (TPK), pedagogical content (PCK), and TPACK across the three knowledge edge domains[5]. The TPACK framework has been used frequently in the past decades in both the pre-service and occupational teacher knowledge studies[3].

Various studies on the ability of TPACK preservice teachers have become benchmarks that an important teacher has the ability to integrate technology with pedagogical abilities and knowledge of material content. Such as research conducted by Chai, Koh \& Tsai which reviewed 74 journals about TPACK regarding the investigation of ICT integration within the TPACK framework[6]. This will be important to do to find out the technology integration in the TPACK framework. Besides, investigations related to the distribution of journals are also needed, the types of research used, the data collection methods used in the research in the reviewed journals to open up opportunities for further researchers to conduct research that takes the topic of TPACK. The objectives of this study are: 1) investigation of journal distribution, 2) investigation of journal research types in percentage of\%, 3) investigation of data collection methods in journals in percentage of $\%, 4)$ TPACK domain investigation that is integrated with its technology and indicators, and 5) research results related to pre-service science teacher TPACK.

\subsection{Theoretical TPACK}

The TPACK level component that integrates with technology is TPACK which is a combination of technological knowledge, pedagogy, and content. TPACK is an understanding, knowledge, and communication of concept representations using technology, pedagogical techniques, knowledge of concepts whether difficult or easy to learn and knowledge of how to help and develop students[9]. However, the technological knowledge referred to in the TPACK study is general knowledge related to digital technology. For this reason, technological knowledge is largely seen as knowledge of computers, the internet/web, and digital materials[8]. So Technological Pedagogical and Content Knowledge (TPACK) is knowledge combining technology with pedagogical abilities and mastery of material content to be conveyed in learning

Knowledge is a collection of information needed to achieve functions and goals; the capacity to organize information based on data and turn it into useful and meaningful information; the capacity in which a person thinks creatively, interprets and acts, and an attitude that makes people want to think[9]. Therefore, TPACK combines integrated knowledge and forms of strategic thinking: to know when, where, and how to use certain knowledge domains and strategies when guiding students to learn by integrating appropriate information and communication technology[10]. If the integration of technology is carried out properly, TPACK will be able to support teachers to be able to organize, implement, criticize the results, and abstract a certain learning plan tailored to the needs of students.

The use of information technology is following that proposed by the Committee of Information Technology Literacy of the National Research Council (NRC). The following is a picture of the TPACK framework:

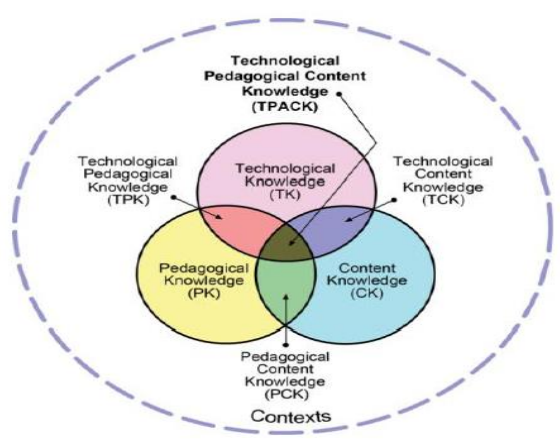

Figure 1. Schematic of the TPACK structure from Shulman [13] 
The TPACK framework was developed by adding technological know-how to Shulman's idea of PCK. The TPACK framework consists of seven subdimensions of knowledge. The main components are technological knowledge (TK), pedagogy (PK), and content (CK). The main domain combination produces a cross between the domains namely pedagogical knowledge technology (TPK), technology content knowledge (TCK), pedagogical content knowledge (PCK). The merging of the three domains as a whole will result in knowledge of content pedagogical technology (TPACK) (Figure 1.). In science learning, technology pedagogic knowledge is needed to relate how knowledge about science content is learned by students, besides how pedagogical knowledge related to science content and how technology knowledge is used to find out which technology is suitable for teaching and learning science [12].

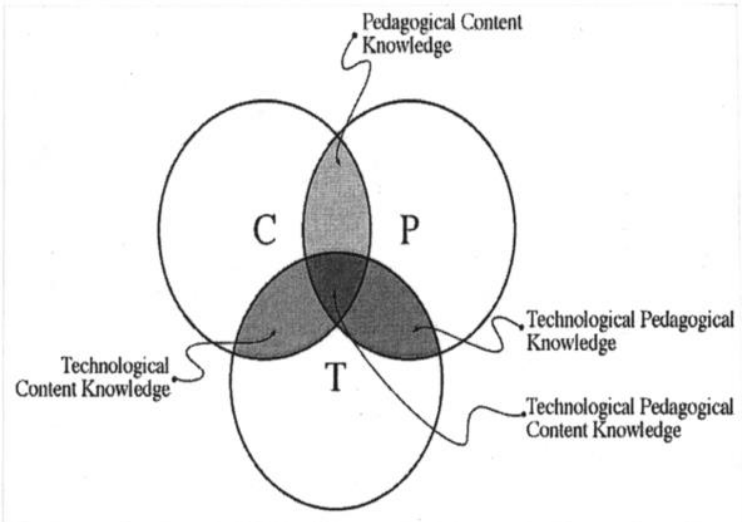

Figure 2. Components of technological pedagogical and content knowledge [13].

The intersection between the technological (T), content (C), and pedagogic (P) domains will be obtained by 3 sub domains if they are integrated with technology, namely technological knowledge (TK), technological pedagogical knowledge (TPK) and technological content knowledge (TCK).

\section{METHOD}

This study uses a literature study research design where in this study using a variety of literature both from articles, journals, and other relevant sources. The literature review is a statistical technique that combines various research results with similar problems, so that it will produce a combination of quantitative and systematic data, in order to draw conclusions. The process of analyzing articles or journals is carried out using 4 steps, namely formulating problems, searching for literature, evaluating and analyzing, and interpreting. In this literature study, data collection was carried out by collecting research results from related scientific articles about pre-service science teacher TPACK. Search for journals, articles, or essays that are conducted over the internet by searching for related pre-service science teacher TPACK abilities.

All studies published in the period 2010-2020 or are studies conducted in the last 10 years with research results that can strengthen the author in conducting his analysis. The data collection process was carried out by identifying the observed variables through the coding method. The coding was carried out by adjusting the research variables, namely: research type and design, data collection methods, and research results on research related to pre-service science teacher TPACK.

After that, the data that has been collected will be analyzed using descriptive statistical techniques. The population in this study are all written documents regarding educational research that discuss the ability of pre-service teacher TPACK. The sample used in this study was 10 research articles. Sampling was done using purposive sampling. This is determined based on conformity with the theme of this research because data or information will be obtained through samples.

The data analysis in this study used quantitative analysis with percentages and qualitative data analysis with the data from the narrative study in the found studies. The journal analyzed were 30 journals but 10 articles that met the requirements or criteria were taken from national and international journals. The division of 10 articles of research subjects can be seen in the grouping Table 1.

Table 1. Distribution of research samples

\begin{tabular}{|c|c|c|l|l|}
\hline No. & Reference & Year & Research design & Data collection technique \\
\hline 1. & {$[28]$} & 2019 & Quantitative & $\begin{array}{l}\text { Survey (single survey and relational } \\
\text { survey) }\end{array}$ \\
\hline 2. & {$[26]$} & 2018 & Correlational analysis & $\begin{array}{l}\text { Survey (web 2.0 usage situation survey } \\
\text { and TPACK self-efficacy confidence }\end{array}$ \\
\hline
\end{tabular}




\begin{tabular}{|c|c|c|l|l|}
\hline No. & Reference & Year & Research design & Data collection technique \\
\hline 3. & {$[27]$} & 2017 & Descriptive quantitative & Scale \\
\hline 4. & {$[29]$} & 2013 & $\begin{array}{l}\text { Development of the TPACK } \\
\text { instrument to determine pre- } \\
\text { service science teacher self- } \\
\text { efficacy beliefs }\end{array}$ & Survey (questionnaire) \\
\hline 5. & {$[8]$} & 2016 & $\begin{array}{l}\text { Development of the TPACK self- } \\
\text { efficacy scale instrument for pre- } \\
\text { service science teachers }\end{array}$ & Survey (questionnaire) \\
\hline 6. & {$[4]$} & 2015 & $\begin{array}{l}\text { Comparison } \\
\text { Quantitative }\end{array}$ & Survey \\
\hline 7. & {$[25]$} & 2020 & Self-managed survey \\
\hline 8. & {$[3]$} & 2019 & $\begin{array}{l}\text { Descriptive } \\
\text { (open questionnaire) }\end{array}$ \\
\hline 9. & {$[2]$} & 2019 & Quantitative & Survey \\
\hline 10 & {$[14]$} & 2017 & $\begin{array}{l}\text { Mixed (quantitative and } \\
\text { qualitative) }\end{array}$ & $\begin{array}{l}\text { Survey (open questionnaire), semi } \\
\text { structured interview }\end{array}$ \\
\hline
\end{tabular}

\section{RESULT AND DISCUSSION}

The results of the literature study will be presented in 5 parts, namely the first part of the distribution of journals, the two types of research in journals, the third investigative data collection methods used in journals, the four TPACK domains that are integrated with technology and indicators, and finally the research results related to the TPACK ability of pre-service science teachers.

\subsection{Journal Distribution Investigations}

Distribution investigations are carried out to find out that research on TPACK is still a research trend every year. Data on the distribution of the 10 journals that were reviewed can be seen in table 2 .

The data in Table 2 shows that the spread of research from the 2010-2020 range in the journals reviewed had the greatest spread in 2016-2020 with a percentage of $80 \%$ who conducted research related to TPACK from 10 journals.

\subsection{Investigating Research Types in Journals}

Investigations of the types of research in journals are carried out to find out what types of research may be used in research that takes the topic of TPACK. From the results of the investigation it can be said that TPACK is a flexible research topic because it can be used for qualitative, quantitative, mixed, descriptive, descriptive, research types, correlation, instrument development and comparison.

The data in Table 3 shows that research on TPACK with the type of quantitative research and instrument development is the most widely used research to examine the TPACK ability of teachers by having a presentation of $40 \%$ and $20 \%$ of 10 articles. This shows that this research is still in great

Table 2. Journal distribution

\begin{tabular}{|c|c|c|c|l|}
\hline No. & Year & Amount & Total Percentage (\%) & Reference \\
\hline 1. & $2010-2015$ & 2 & 20 & {$[4],[29]$} \\
\hline 2. & $2016-2020$ & 8 & 80 & {$[2],[3],[8],[14],[25],[26],[27],[28]$} \\
\hline
\end{tabular}

Table 3. Category types of research in journals

\begin{tabular}{|c|l|c|c|l|}
\hline No. & Types of research & Amount & $\begin{array}{l}\text { Total Percentage } \\
(\%)\end{array}$ & Reference \\
\hline 1 & quantitative & 4 & 40 & [2], [25], [27], [28] \\
\hline 2 & $\begin{array}{l}\text { Mixed (quantitative and } \\
\text { qualitative) }\end{array}$ & 1 & 10 & {$[14]$} \\
\hline
\end{tabular}




\begin{tabular}{|c|l|c|c|l|}
\hline 3 & Descriptive & 1 & 10 & {$[3]$} \\
\hline 4 & Correlational & 1 & 10 & {$[26]$} \\
\hline 5 & Instrument Development & 2 & 20 & {$[8],[29]$} \\
\hline 6 & Comparison & 1 & 10 & {$[4]$} \\
\hline
\end{tabular}

demand by researchers, besides research by developing instruments that can be used as a measuring tool that can be used by further researchers to measure the teacher's TPACK ability by re-testing it on different individuals and numbers.

\subsection{Investigative Data Collection Methods Used in Journals}

The data in Table 4 shows that research on TPACK uses more of the data collection method using a questionnaire (survey) where $100 \%$ of the 10 articles use this method. Also, there are $10 \%$ of 10 studies that se more than one data collection method conducted by Levent that uses questionnaires and interviews [14]. The surveys used varied, from surveys using open questionnaires, simple descriptive surveys, single and relational surveys, self-managed surveys and surveys before and after participating in the program.

Formulas are used to obtain the presentation:

$\frac{\text { Number of articles }}{\text { The total number of articles reviewed }}$ X100\%

The formula is used to find the percentage in percent $(\%)$ of each table that looks for percentage data.

\subsection{TPACK Domain Investigation That is Integrated with Its Technology and Indicators}

This section provides an overview of the TPACK framework that integrates technology in pre-service teachers. Within the TPACK framework, three
TPACK levels integrate with technology, namely TK, TPK, and TCK. Each TPACK level that integrates with technology has various indicators that can be used to determine the TPACK ability of pre-service teachers.

\subsubsection{Technological Knowledge (TK)}

The TPACK level which integrates technology furthermore technological knowledge (TK) is the expertise in technology related to information and skills in using certain technologies [15]. Ability in technology or technological knowledge cannot be separated from the subject. Technology that can range from low technology with pencil and paper to digital technology [8]. Information technology knowledge (TK) contains multimedia and PowerPoint. Apart from that, digital technology can also be in the form of the internet, digital video, interactive whiteboards, and software programs [16].

Teachers who have extensive knowledge about the productive use of technology can help students learn more effectively and solve problems than those without technology knowledge[18]. So it can be said that technological knowledge (TK) is information knowledge and skills in using technology both from low technology to digital technology such as the internet and must pay attention to subjects that will make a teacher productive in helping student lessons more effectively. The TK indicators according to Chai C.S, Koh, Tsai, \& Tan, and Seyit A.K are shown in Table 5. [18][8].

Table 4. Data collection methods in journals

\begin{tabular}{|l|l|c|c|l|}
\hline No. & Methods & Amount & $\begin{array}{l}\text { Total Percentage } \\
(\%)\end{array}$ & Reference \\
\hline 1. & Survey & 10 & 100 & {$[2],[3],[4],[8],[14],[25],[26],[27],[28],[29]$} \\
\hline 2. & Interview & 1 & 10 & {$[14]$} \\
\hline
\end{tabular}

\subsubsection{Technological Pedagogical Knowledge (TPK)}

The TPACK level integrates technology with pedagogic, namely technological pedagogical knowledge (TPK). $\quad$ Technological $\quad$ Pedagogical Knowledge (TPK) refers to knowledge of how various technologies can be used in teaching or teaching[20]. Besides, to understand that using technology can affect there are ways teachers teach[16]. Teachers who feel sufficient in terms of 
TPK must have the ability to decide which technological devices are suitable for educational use. At the same time, they must be able to integrate the technology they are most comfortable with with the most appropriate teaching strategy, method, technique, model or theory. Similar to this, teachers must be able to integrate technology in education using measurement and assessment methods and techniques, in the use of technology teachers must be able to adapt to differences in individual student abilities, and have the ability to manage the classroom environment. In short, the TPK is related to the presentation of pedagogical strategies and technology integration[20]. So in other words the ability of technological pedagogical knowledge where a teacher can customize the model, method, learning strategy must pay attention to the right technology that must be used in learning.

The use of technology in teaching is changing teaching methods and promoting the benefits of learning. Combining pedagogical knowledge and technological instruments, curriculum design can be more disciplined and effective in addressing the real needs of students[17]. The TPK indicators according to Chai C.S, Koh, Tsai, \& Tan and Seyit A.K are shown in Table 5.[19][8].

\subsubsection{Technological Content Knowledge (TCK)}

The TPACK level that integrates technology with content is technology content knowledge (TCK). Knowledge of the material relationship between learning and technology includes certain material content that has been explored by using and using technology[21]. Also, there is a knowledge of technology content that can provide a new representation for certain content. When the teacher's understanding of using technology shows that the teacher can create or change the way students learn to understand the concepts in certain content[16]. How to choose the technology that can best embody and support specific content-based teaching[19]. Knowledge of integrating existing technology to specific subject matter knowledge which does not include pedagogical purposes, knowledge of the application of simulations to inform development [22].

Practitioners in content disciplines such as data collection and analysis tools (digital probes and spreadsheets by scientists) and knowledge of technology tools illustrate content technology knowledge (TCK)[2]. TCK is knowledge using technology to denote specific content areas [24]. By taking advantage of advances in technology, teachers can use new perspectives to describe phenomena in the content area [17]. The TCK indicators according to Chai C.S, Koh, Tsai, \& Tan and Seyit A.K are shown in Table 5. [18][8].

\subsection{Research Results Related to The Ability of Pre-Service Science Teacher TPACK}

The results of the analysis obtained from journal investigations related to the results of research on the integration of technological knowledge and content pedagogy (TPACK) in pre-service science teachers can be seen in table 6 .

The belief in the self-efficacy of pre-service science teachers on the ability of TPACK teachers can be influenced by the frequency of use of social media in kindergarten, TPK and TPACK[25]. However, it is not specifically influenced by gender differences[4]. However, this is different from the research conducted by Belgin Wright that there are differences based on gender in the 6 sub-dimensions of TPACK except in technological knowledge (TK)[26]. Also, the courses or training carried out can contribute to the development of TPACK for preservice teachers, especially in the sub-dimensions $\mathrm{T}$, TCK and TPK. [27][14]. The teacher's ability at each TPACK level can be a higher impact on student academic achievement which explains $12 \%$ of the influence on student academic achievement [28].

Table 5. Indicators of TK, TPK and TCK

\begin{tabular}{|l|l|}
\hline Aspect & Indicator \\
\hline Technological & Able to use the internet / web in biology learning (ex: blog, Facebook, wiki) \\
Knowledge (TK) & $\begin{array}{l}\text { Able to use technology easily and have the ability to use technology techniques } \\
\text { Able to use work applications (MS Word, Excel and Power Point) } \\
\text { Able to use software and applications in learning (ex: MSN Messenger, Skype, Yahoo, IM) } \\
\text { Able to use learning resources on the website }\end{array}$ \\
\hline
\end{tabular}




\begin{tabular}{|l|l|}
\hline $\begin{array}{l}\text { Technological } \\
\text { Pedagogical } \\
\text { Knowledge } \\
\text { (TPK) }\end{array}$ & $\begin{array}{l}\text { Able to use information and communication technology for discussion in forums with } \\
\text { students } \\
\text { Able to use technology that supports student independence and communication } \\
\text { Able to use technology that supports students' thinking skills (critical and creative thinking) } \\
\text { Able to adjust the use of technology that has been learned in various teaching activities }\end{array}$ \\
\hline $\begin{array}{l}\text { Technological } \\
\text { Content } \\
\text { Knowledge } \\
\text { (TCK) }\end{array}$ & $\begin{array}{l}\text { Able to use appropriate technology (eg multimedia resources, simulations) to represent } \\
\text { course content } \\
\text { Able to choose appropriate learning basic competency materials in teaching using } \\
\text { technology } \\
\text { Able to determine learning materials that require technological facilities to facilitate students } \\
\text { in lessons }\end{array}$ \\
\end{tabular}

Table 6. Analysis of research results

\begin{tabular}{|c|c|c|}
\hline Reference & $\begin{array}{l}\text { Result } \\
\text { indicator }\end{array}$ & Research result \\
\hline $\begin{array}{l}\text { [28], [3], } \\
\text { [25], [4] }\end{array}$ & $\begin{array}{l}\text { Self-efficacy } \\
\text { beliefs through } \\
\text { social media, as } \\
\text { a predictor of } \\
\text { academics and } \\
\text { based on } \\
\text { gender }\end{array}$ & $\begin{array}{l}\text { Social media: frequency of use has a high correlation with self-efficacy at TK, } \\
\text { TPK, and TPACK statistically (high correlation with } \mathrm{r}>0.5 \text { ) } \\
\text { Predictors of student achievement: teacher TPACK level, student self- } \\
\text { efficacy, academic, social, and emotional explained } 12 \% \text { of student } \\
\text { academic achievement. Teacher's TPACK level has a higher impact on } \\
\text { student academic achievement. } \\
\text { Gender: gender differences do not affect the level of self-efficacy of pre- } \\
\text { service science teachers on technology integration statistic even though they } \\
\text { differ in mean scores }\end{array}$ \\
\hline [26], [2] & $\begin{array}{l}\text { Reliability and } \\
\text { response of } \\
\text { prospective } \\
\text { teachers }\end{array}$ & $\begin{array}{l}\text { Scale reliability: Cronbach alpha }(\alpha) \text { results with the internal consistency } \\
\text { factor of the scale of } 0.989 \text { on self-efficacy beliefs. Meanwhile, Cronbach } \\
\text { alpha }(\alpha) \text { in the use of web } 2.0 \text { applications ranging from } 0.716 \text { is said to be } \\
\text { reliable because Cronbach alpha ( } \alpha \text { ) from the use of web } 2.0 \text { applications is } \\
0.936 \text {. } \\
\text { Teacher candidate responses: } 1) \text { in general, the TPACK scale of teacher } \\
\text { self-efficacy beliefs was found in PK with the highest average }(7.9822) \text { and } \\
\text { kindergarten with the lowest average ( } 7.1683) \text { and the answer scale on the } \\
\text { highest TPACK self-efficacy belief in "me sure I can "with an average of } \\
7,8340 \text {. 2) The level of confidence level of TPACK self-efficacy based on } \\
\text { gender on } 6 \text { subdimensions was found to have a higher score for women } \\
\text { than men ( } p<0.05) \text { except in kindergarten. }\end{array}$ \\
\hline [27], [14] & $\begin{array}{lr}\text { TPACK } & \text { pre- } \\
\text { service } & \text { science } \\
\text { teacher } & \text { with } \\
\text { courses } & \end{array}$ & $\begin{array}{l}\text { 1) The ability of TPACK pre-service science teachers is increased by taking } \\
\text { courses or training from grade } 1 \text { to grade } 4 \text { (through technology courses and } \\
\text { material design that have an active role in software development) in } \\
\text { integrating technology. } \\
\text { 2) The implementation of courses contributes to the development of pre- } \\
\text { service teachers especially in the sub-dimensions T, TCK, and TPK. }\end{array}$ \\
\hline [8], [29] & $\begin{array}{l}\text { Validity, } \\
\text { Reliability, and } \\
\text { Results }\end{array}$ & $\begin{array}{l}\text { Validity: carried out with construct and content validity. A scale with } 55 \text { items } \\
\text { was determined and confirmed by confirmatory factor analysis. On the } \\
\text { TPACK-SeS scale with } 52 \text { items using EFA and CFA analysis. } \\
\text { Reliability: Cronbach alpha ( } \alpha \text { ) value with internal consistency factor on } \\
\text { subdimension above } 0.70 \text {. } \\
\text { Results: } 1) \text { scale development by classifying technology from traditional to } \\
\text { digital and the internet. The advantages of the scale are the literature with } \\
\text { the names of the technology listed, 2) TPACK-SeS can function to evaluate } \\
\text { the self-efficacy beliefs of pre-service science teachers for teachers, } \\
\text { researchers and educators. }\end{array}$ \\
\hline
\end{tabular}

\section{CONCLUSSION}

Based on the results and discussion, the conclusions are as follows: a. The largest distribution of journals in the 20162020 period with a percentage of $80 \%$

b. The type of research that many journals use in this literature study is quantitative research with 
a percentage of $40 \%$ and was followed by the development of the TPACK instrument.

c. Data collection methods that are widely used in journals are dominated by serving or almost all journals that are carried out by literature studies.

d. In the integration of technology within the TPACK framework, there are 3 technologyintegrated sub-dimensions, namely technological knowledge (TK), technology pedagogic knowledge (TPK), and technology content knowledge (TCK).

e. Technology integration within the TPACK framework can be increased with pre-service science teachers conducting training or technology integration courses in TPACK. Besides, self-efficacy beliefs can also affect the integration of technology and also the use of social media. However, it is not specifically affected by gender differences. Teacher's TPACK levels can also affect student academic achievement.

\section{ACKNOWLEDGMENTS}

Thank you to all those who helped carry out this research.

\section{REFERENCES}

[1] N. Kumar, R. C. Rose, J. L. D'Silva, Teachers' readiness to use technology in the classroom: An empirical study, European Journal of Scientific Research 21(4) (2018) 603-616.

[2] U. Kul, Z. Aksu, S. Birisci, The Relationship between Technological Pedagogical Content Knowledge and Web 2.0 Self-Efficacy Beliefs, International Online Journal of Educational Sciences 11(1) (2019) 198-213. DOI: https://doi.org/10.15345/iojes.2019.01.014

[3] M. Irmak and Ö. Yilmaz Tüzün, Investigating pre-service science teachers' perceived technological pedagogical content knowledge (TPACK) regarding genetics, Research in Science \& Technological Education 37(2) (2019) 127-146. DOI: https://doi.org/10.1080/02635143.2018.1466778

[4] H. Keser, F. G. Karaoğlan Yılmaz, R. Yılmaz, TPACK Competencies and Technology Integration Self-Efficacy Perceptions of PreService Teachers, Elementary Education Online İlköğretim Online 14(2) (2015), 1193-1207. DOI: http://doi.org/10.17051/io.2015.65067

[5] M. J. Koehler, P. Mishra, Technological
Pedagogical Content Knowledge: A Framework for Teacher Knowledge, Teachers College Record 108(6) (2006) 1017-1054.

[6] C. S. Chai, J. H. L. Koh, C.-C. Tsai, International Forum of Educational Technology \& Society A Review of Technological Pedagogical Content Knowledge, Source: Journal of Educational Technology \& Society 16(2) (2013) 31-51. DOI: https://doi.org/10.2307/jeductechsoci.16.2.31

[7] M. Yigit, A Review of the Literature: How Preservice Mathematics Teachers Develop Their Technological, Pedagogical, and Content Knowledge, International Journal of Education in Mathematics, Science and Technology 2(1) (2014) 25-35. DOI: http://doi.org/10.18404/ijemst.96390

[8] S. A. Kiray, Development of a TPACK Selfefficacy Scale for Preservice Science Teachers, International Journal of Research in Education and Science 2(2) (2016) 527-540. DOI: http://doi.org/10.21890/ijres.64750

[9] R. P. uit Beijerse, Knowledge management in small and medium-sized companies: knowledge management for entrepreneurs, Journal of Knowledge Management 4(2) (2000) 162-179. DOI:

https://doi.org/10.1108/13673270010372297

[10] R. Shavelson, M. A. Ruiz-Primo, M. Li, Evaluating New Approaches to Assessing Learning CSE Report 604 Richard Shavelson and Maria Araceli Ruiz-Primo CRESST / University of California, Los Angeles Min Li University of Washington Carlos Cuauhtemoc Ayala California State University, Sonoma Augu, Population (English Edition), vol. 1522, no. 310,2003 , pp. 1-31.

[11] S. Suyanto, H. Nurcahyo, I. M. Ixora, Comparative Study on the Development of Technological, Pedagogical and Content Knowledge (TPACK) of Biology Teacher Through Academic and Professional Program, International Journal of Research in Teacher Education 10(1) (2019) 41-53.

[12] B. Kartal, C. Çinar, Examining Pre-Service Mathematics Teachers' Beliefs of TPACK during A Method Course and Field Experience, Malaysia Online Journal of Educational Techology 6(3) (2018) 11-37. DOI: http://dx.doi.org/10.17220/mojet.2018.03.002

[13] M. J. Koehler, P. Mishra, What Happens When Teachers Design Educational Technology?, Journal of Educational Computing Research 
Environmental Science and Technology, 32(2) (2005) 131-152. DOI: https://pubs.acs.org/doi/10.1021/acs.est.6b0430 $\underline{2}$

[14] L. Durdu, F. Dag, Pre-Service Teachers' TPACK Development and Conceptions through a TPACK-Based Course, Australian Journal of Teacher Education 42(11) (2017) 150-171.

[15] B. Ergen, T. Yanpar Yelken, S. Kanadli, A Meta-Analysis of Research on Technological Pedagogical Content Knowledge by Gender, Contemporary Educational Technology 10(4) (2019) 358-380. DOI: https://doi.org/10.30935/cet.634182

[16] D. A. Schmidt, A. D. Thompson, M. J. Koehler, T. S. Shin, Technological Pedagogical Content Knowledge (TPACK): The Development and Validation of an Assessment Instrument for Preservice Teachers, CIE 2014 - 44th International Conference on Computers and Industrial Engineering and IMSS 2014 - 9th International Symposium on Intelligent Manufacturing and Service Systems, Joint International Symposium on "The Social Impacts of Developments in Information", vol. 42, no. 2, 2014, pp. 123-149.

[17] C. J. Wang, Facilitating the emotional intelligence development of students: Use of technological pedagogical content knowledge (TPACK), Journal of Hospitality Leisure Sport and Tourism Education 25 (2019) 100198. DOI: https://doi.org/10.1016/j.jhlste.2019.100198

[18] C. S. Chai, J. H. Ling Koh, C. C. Tsai, L. Lee Wee Tan, Modeling Primary School Pre-Service Teachers' Technological Pedagogical Content Knowledge (TPACK) for Meaningful Learning With Information And Communication Technology (ICT), Computers and Education 57(1) (2011) 1184-1193. DOI: http://dx.doi.org/10.1016/j.compedu.2011.01.00 7

[19] J. B. Harris, M. J. Hofer, Technological Pedagogical Content Knowledge (TPACK) in Action, Journal of Research on Technology in Education 43(3) (2011) 211-229. DOI: http://doi.org/abs/10.1080/15391523.2011.1078 2570

[20] M. J. Koehler, P. Mishra, W. Cain, What is Technological Pedagogical Content Knowledge (TPACK)?, Journal of Education 193(3) (2013) 13-19.

DOI: http://doi.org/10.1177/002205741319300303

[21] J. T. Abbitt, Measuring Technological
Pedagogical Content Knowledge in Preservice Teacher Education, Journal of Research on Technology in Education 43(4) (2011) 281-300. DOI:

https://doi.org/10.1080/15391523.2011.1078257 3

[22] M. Muhaimin et al., A Sequential Explanatory Investigation of TPACK: Indonesian Science Teachers' Survey and Perspective, Journal of Education and Training Studies 9(3) (2019) 269. DOI: $\underline{\text { https://doi.org/10.11114/jets.v4i10.1816 }}$

[23] A. Tanak, Designing TPACK-Based Course For Preparing Student Teachers to Teach Science with Technological Pedagogical Content Knowledge, Kasetsart Journal of Social Sciences $30 \quad$ (2018) 1-7. DOI: https://doi.org/10.1016/j.kjss.2018.07.012

[24] D. A. Schmidt, E. Baran, A. D. Thompson, P. Mishra, M. J. Koehler, T. S. Shin, Technological Pedagogical Content Knowledge (TPACK), Journal of Research on Technology in Education 42(2) (2009) 123-149. DOI: http://doi.org/10.1080/15391523.2009.1078254 4

[25] H. Setiawan, S. Phillipson, The Correlation Between Social Media Usage in Academic Context and Self-Efficacy Towards TPACK of Prospective Science Teachers in Indonesia, Journal of Science Learning 3(2) (2020) 106116.

DOI: https://doi.org/10.17509/jsl.v3i2.22242

[26] B. Wright, D. Akgunduz, C. Education, The Relationship Between Technological Pedagogical Content Knowledge (TPACK) Self-Efficacy Belief Levels and The Usage of Web, World Journal on Educational Technology: Current Issues 10(1) (2018) 52-69.

[27] B. Can, S. Erokten, A. Bahtiyar, An Investigation of Pre-Service Science Teachers' Technological Pedagogical Content Knowledge, European Journal of Educational Research 6(1) (2017) 51-57. DOI: https://doi.org/ 10.12973/eu-jer.6.1.51

[28] A. O. Akturk, H. S. Ozturk, Teachers' TPACK Levels and Students' Self-Efficacy as Predictors of Students' Academic Achievement, International Journal of Research in Education and Science 5(1) (2019) 283-294.

[29] S. C. Bİlİcí, H. Yamak, N. Kavak, S. S. Guzey, Self-Efficacy Scale (TPACK-SeS) for PreService Science Teachers: Construction, Validation, and Reliability, Eurasian Journal of Educational Research 52 (2013) 37-60. 